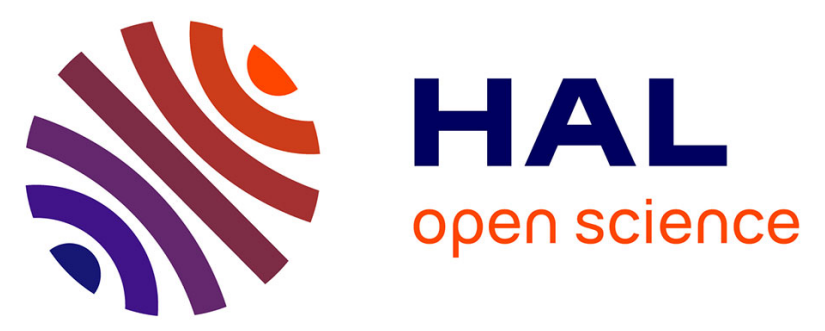

\title{
Evaluation of whole-blood conservation reagents for Hematoflow-based WBC differential count: Unsatisfactory results
}

Orianne Wagner-Ballon, Bouchra Badaoui, Audrey Brignoli, Jérôme Le Priol, Mikael Roussel

\section{To cite this version:}

Orianne Wagner-Ballon, Bouchra Badaoui, Audrey Brignoli, Jérôme Le Priol, Mikael Roussel. Evaluation of whole-blood conservation reagents for Hematoflow-based WBC differential count: Unsatisfactory results. International Journal of Laboratory Hematology, 2017, 39 (5), pp.e127-e131. 10.1111/ijlh.12697 . hal-01616400

HAL Id: hal-01616400 https://hal-univ-rennes1.archives-ouvertes.fr/hal-01616400

Submitted on 10 Nov 2017

HAL is a multi-disciplinary open access archive for the deposit and dissemination of scientific research documents, whether they are published or not. The documents may come from teaching and research institutions in France or abroad, or from public or private research centers.
L'archive ouverte pluridisciplinaire HAL, est destinée au dépôt et à la diffusion de documents scientifiques de niveau recherche, publiés ou non, émanant des établissements d'enseignement et de recherche français ou étrangers, des laboratoires publics ou privés. 


\title{
Evaluation of whole blood conservation reagents for Hematoflow-based WBC differential count; unsatisfactory results
}

\author{
Orianne Wagner-Ballon, ${ }^{1,2}$ Bouchra Badaoui ${ }^{1,2}$, Audrey Brignoli, ${ }^{1}$ Jerome Le \\ Priol, ${ }^{3}$ Mikael Roussel ${ }^{3,4}$
}

1 Hôpitaux universitaires Henri Mondor, Département d'Hématologie et d'Immunologie biologiques, F-94010 Creteil, France

2 UPEC, F-94010 Creteil, France

${ }^{3}$ CHU Rennes, Laboratoire d'Hématologie, Pôle de Biologie, F-35033 Rennes, France

4 INSERM, UMR U1236, Université Rennes 1, EFS Bretagne, Equipe Labellisée Ligue Contre le Cancer, F-35043 Rennes, France

Corresponding author: Mikael Roussel,Laboratoire d'Hématologie, CHU Pontchaillou, 2 rue Henri Le Guilloux, 35033 Rennes Cedex 9, France; Phone: +33 299289 142; Fax: +33 299284 152; Email: mikael.roussel@chu-rennes.fr

Brief title: Effect of blood storage for WBC differential by Hematoflow

Keywords: Flow Cytometry; Leukocyte differential; blood preservation; Transfix; Streck Cell Preservative.

Total word count: 979 


\section{Abstract}

\section{Background:}

As conservation of whole blood samples undergoing white blood cell (WBC) differential performed by flow cytometry (Hematoflow) is needed, we evaluated the effects of two commercially available fixatives, namely Transfix ${ }^{\mathrm{TM}}$ and Streck Cell Preservative ${ }^{\mathrm{TM}}$.

\section{Methods:}

We focused on 15 normal samples and on 13 various pathological samples. We compared the two fixatives and cold- or room- temperature effects on various parameters provided by the Hematoflow system.

\section{Results:}

We observed that, even after 2 hours of sample treatment, the conservative methods led to significant modifications of the cell percentages due to substantial variations of the epitope expression.

\section{Conclusion:}

None of the different conservation methods is really reliable for WBC differential performed by flow cytometry and thus samples should be analyzed promptly or stored at $4^{\circ} \mathrm{C}$ 
Complete Blood Count (CBC) and its White Blood Cell (WBC) differential count remains one of the most useful laboratory investigations for the diagnosis of various systemic or blood diseases. Multiparameter flow cytometry (MFC) has recently been demonstrated as a relevant tool to replace part of the conventional smear microscopic review [1-5]. On this novel application, a CE (European Conformity)-marked cocktail of antibodies, CytoDiff ${ }^{\mathrm{TM}}$, on a dedicated flow cytometric platform, HematoFlow ${ }^{\mathrm{TM}}$ (Beckman Coulter, Brea, CA), has been successfully integrated into the routine workflow of our laboratories [6]. In our organizations, the flow cytometric platform cannot be kept on after the working hours, therefore part of the analysis has to be postponed and samples have to be stored overnight or over the whole weekend, leading to potential instability of blood samples. External Quality Control (EQC) programs are essential for reliability and accreditation of this cytometry method [7]. Also, optimized fixation procedures have to be determined for whole blood samples undergoing WBC differential count by flow cytometry, in particular, with Hematoflow ${ }^{\mathrm{TM}}$ where an automatic gating is now available (CytoDiff ${ }^{\mathrm{TM}}$ 2.0, Beckman Coulter) requiring fluorescence intensity is stable within acceptable limits [8].

Up to now, different stabilizing reagents have been developed for cellular preservation such as Transfix $^{\mathrm{TM}}$ (Cytomark, UK) and Streck Cell Preservative ${ }^{\mathrm{TM}}$ (formerly Cyto-Chex ${ }^{T M}$, Streck Laboratories) $[9,10]$. Both were targeted in different studies for many years and were evaluated either for cellular count or marker intensity preservation [11]. Streck Cell Preservative ${ }^{\mathrm{TM}}$ appeared as a better alternative for preserving absolute cell count compared with Transfix, however this latter enables a better marker intensity preservation $[7,11]$. 
We aimed to compare the two commercial fixatives, Transfix ${ }^{\mathrm{TM}}$ and Streck Cell Preservative ${ }^{\mathrm{TM}}$ with our standard procedure for WBC differential count performed by Hematoflow. The blood samples were drawn from normal samples ( $n=11$ healthy donors and $n=4$ cord bloods) and from patients ( $n=13$, pathological samples) (Table 1), and analyzed on two Hematoflow platforms. Blood was fixed, following manufacturers' recommendations, with Streck Cell Preservative ${ }^{\mathrm{TM}}$ reagent and Transfix ${ }^{\mathrm{TM}}$ storage tubes. As control, cells were also kept at room temperature and at $+4^{\circ} \mathrm{C}$. Samples were analyzed in the laboratories after 2 hours.

First, we evaluated the effect of the conservation method on key marker expressions for the Cytodiff autogating. In the normal samples (healthy donors and cord bloods), we focused on mean florescence intensity (MFI) of CD16, CD19, CD2, CD36, and CD45 expressions on positive cell populations: neutrophils, B-lymphocytes, T\&NK cells, monocytes, and total WBCs respectively (Figure 1). All these marker expressions were not modified when samples were kept either at room temperature $(\mathrm{RT})$ or at $+4^{\circ} \mathrm{C}$. However, when Streck Cell Preservative $^{\mathrm{TM}}$ was used, an underexpression of CD19, CD36, and CD45 was observed on B-lymphocytes, monocytes, and total WBC, respectively. The use of Transfix ${ }^{T M}$ led to an underexpression of CD16, CD19, CD2, and CD45 on neutrophils, B-lymphocytes, T\&NK cells, and total WBC, respectively. Therefore, we concluded that both fixatives cause substantial variations of the epitope even after 2 hours (Figure 1). These discrepancies were also noticed on pathological samples (data not shown). Then, we analyzed a set of thirteen pathological samples, which were taken from patients who had quantitative and/or qualitative 
cell population anomalies in their blood (detailed in Table 1). Although there were no statistically significant changes, discrepancies higher than $5 \%$ were observed on neutrophil, lymphocyte, and blast populations notably when both fixatives were used (data not shown). Examples of CD45/SSC scattergram of a normal sample and a pathological sample analyzed after 2 hours of fixation are shown in Figure 2. Of note, the major difference was seen in a sample containing both Blymphoblast cells and residual normal B-lymphocytes (pathological sample \#2). In this case, part of B-blast cells were classified as B-lymphocytes after 2 hours of cold storage alone ( $22 \%$ vs $54 \%$ when stored at room temperature), whereas upon using either Streck Cell Preservative ${ }^{\mathrm{TM}}$ or Transfix $^{\mathrm{TM}}$ the percentage of $\mathrm{B}$ blasts increased after fixation (78\% and $80 \%$ respectively vs $54 \%$ when stored at room temperature). We also noticed on a healthy sample, that basophils were classified as blasts upon Streck Cell Preservative ${ }^{\mathrm{TM}}$ or Transfix ${ }^{\mathrm{TM}}$ (Figure 2). On the normal samples, it can be noticed that basophils (in black) detected at room temperature were classified as blast (in red) when preservative solutions were used (Figure 2). According to our results, we concluded that, after only 2 hours, the three conservation methods (cold storage and both fixatives) enhanced misclassifications of cells by the Hematoflow.

We conducted this study to determine which fixation procedures can optimally be used on whole blood samples undergoing a Hematoflow analysis since not all the samples can be analyzed within a single working day. We assessed the effect of different conservation methods, including commercial fixatives and simple cold- or room- temperature storage, on various abnormal cell populations and on normal cell populations obtained from healthy donors, elderly 
patients, or even cord blood. Most of the previous studies, on normal blood samples conservation, were conducted on few samples (precisely 4 to 10) [11]. Here, we analyzed not only 15 normal samples but also additional 13 various pathological samples to cover different representative abnormal populations.

As previously demonstrated [11,12], we found that both fixatives (Transfix ${ }^{\mathrm{TM}}$ or Streck Cell Preservative ${ }^{\mathrm{TM}}$ ) induced more antigenic modulations than the simple cold storage, notably with important gating markers used for Hematoflow autogating e.g. CD19 for B-lymphocytes or CD16 for neutrophils. This effect on CD19 has to be outlined because it is labeled with PE-Texas Red (ECD) in the CytoDiff ${ }^{\mathrm{TM}}$ reagent, which is known to be a dim fluorochrome regularly leading to failed autogating, in particular, when pathological B-cells CD19 low are evaluated [6].

We therefore concluded that none of the different conservation methods is really reliable for Hematoflow-based WBC differential count performed with autogating software, and that samples should be ideally analyzed promptly. However it as to be noticed that based on the manufacturer recommendations Hematoflow analysis is validated up to 24 hours after blood withdrawn. 


\section{Acknowledgments}

The authors would like to thank Mounia Yadini-Foucard (Beckman-Coulter, France) for helpful technical discussions, and Beckman Coulter for supplying reagents. They are especially grateful to Suhad Assad for the English reviewing of the manuscript.

O.W.B and M.R. conceived the study, analyzed data, and wrote the paper; B.B., A.B., and J.L.P. performed experiments and analyzed data. All authors revised and approved the manuscript. 
Table 1. Characterization of the study 28 samples

\begin{tabular}{|c|c|c|c|}
\hline Sample type & $\begin{array}{c}\text { Donor's/Patient's } \\
\text { age }\end{array}$ & $\begin{array}{l}\text { Abnormal cell } \\
\text { populations }\end{array}$ & Disease \\
\hline Normal \#1 & 25 & - & - \\
\hline Normal \#2 & 25 & - & - \\
\hline Normal \#3 & 31 & - & - \\
\hline Normal \#4 & 47 & - & - \\
\hline Normal \#5 & 48 & - & - \\
\hline Normal \#6 & 48 & - & - \\
\hline Normal \#7 & 49 & - & - \\
\hline Normal \#8 & 56 & - & - \\
\hline Normal \#9 & 69 & - & - \\
\hline Normal \#10 & 69 & - & - \\
\hline Normal \#11 & 82 & - & - \\
\hline Cord Blood \#1 & - & - & - \\
\hline Cord Blood \#2 & - & - & - \\
\hline Cord Blood \#3 & - & - & \\
\hline Cord Blood \#4 & - & - & - \\
\hline Pathological \#1 & 54 & Myeloid blasts & $\begin{array}{c}\text { Acute myelomonocytic } \\
\text { leukemia }\end{array}$ \\
\hline Pathological \#2 & 71 & Lymphoid blasts & $\begin{array}{l}\text { B-cell precursor acute } \\
\text { lymphoblastic leukemia }\end{array}$ \\
\hline Pathological \#3 & 71 & $\begin{array}{l}\text { Myeloid blasts, } \\
\text { Immature granulocytes }\end{array}$ & Primary myelofibrosis \\
\hline Pathological \#4 & 66 & $\begin{array}{l}\text { Myeloid blasts, } \\
\text { Immature granulocytes, } \\
\text { basophils }\end{array}$ & $\begin{array}{l}\text { Chronic myeloid } \\
\text { leukemia }\end{array}$ \\
\hline Pathological \#5 & 56 & $\begin{array}{l}\text { Myeloid blasts, } \\
\text { Immature granulocytes }\end{array}$ & Acute myeloid leukemia \\
\hline Pathological \#6 & 24 & Monocytes & $\begin{array}{l}\text { Juvenile } \\
\text { myelomonocytic } \\
\text { leukemia }\end{array}$ \\
\hline Pathological \#7 & 90 & Monocytes & Reactive monocytosis \\
\hline Pathological \#8 & 87 & Monocytes & Reactive monocytosis \\
\hline Pathological \#9 & 32 & Eosinophils & Reactive eosinophilia \\
\hline Pathological \#10 & 42 & Lymphocytes & Mantle cell lymphoma \\
\hline Pathological \#11 & 44 & Lymphocytes & $\begin{array}{l}\text { Non-characterized } \\
\text { lymphocytosis }\end{array}$ \\
\hline Pathological \#12 & 23 & Lymphocytes & $\begin{array}{c}\text { Non-characterized } \\
\text { lymphocytosis }\end{array}$ \\
\hline Pathological \#13 & 52 & Lymphocytes & $\begin{array}{c}\text { Non-characterized } \\
\text { lymphocytosis }\end{array}$ \\
\hline
\end{tabular}

Blood was collected in 4-ml EDTA (K3) vacutainers (Becton Dickinson) from normal samples $(n=15)$ obtained from healthy donors $(n=8)$, elderly patients $(n=3: \# 9, \# 10$, and $\# 11)$, or cord blood $(n=4)$. Pathological samples $(n=13)$ were taken from patients whose blood contains quantitative and/or qualitative abnormal cell populations. 


\section{References}

1. Roussel M, Davis BH, Fest T, Wood BL, on behalf of the International Council for Standardization in Hematology (ICSH). Toward a reference method for leukocyte differential counts in blood: Comparison of three flow cytometric candidate methods. Cytometry A. 2012 Nov;81A(11):97382.

2. Faucher J-L, Lacronique-Gazaille C, Frébet E, Trimoreau F, Donnard M, Bordessoule D, et al. "6 markers/5 colors" extended white blood cell differential by flow cytometry. Cytometry A. 2007 Nov;71(11):934-44.

3. Björnsson S, Wahlström S, Norström E, Bernevi I, O'neill U, Johansson E, et al. Total nucleated cell differential for blood and bone marrow using a single tube in a five-color flow cytometer. Cytometry B Clin Cytom. 2008 Mar 1;74B(2):91-103.

4. Cherian S, Levin G, Lo WY, Mauck M, Kuhn D, Lee C, et al. Evaluation of an 8-color flow cytometric reference method for white blood cell differential enumeration. Cytometry B Clin Cytom. 2010 Sep;78(5):319_ 28.

5. Van De Geijn G-J, Van Rees V, Van Pul-Bom N, Birnie E, Janssen H, Pegels $\mathrm{H}$, et al. Leukoflow: multiparameter extended white blood cell differentiation for routine analysis by flow cytometry. Cytometry A. 2011 Sep;79(9):694-706.

6. Roussel M, Benard C, Ly-Sunnaram B, Fest T. Refining the white blood cell differential: the first flow cytometry routine application. Cytometry A. 2010 Jun;77(6):552-63.

7. Sack U, Barnett D, Demirel GY, Fossat C, Fricke S, Kafassi N, et al. Accreditation of flow cytometry in Europe. Cytometry A. 2013 Mar 28;84B(3):135-42.

8. Cottard A, Wagner-Ballon O, Le Priol J, Azzaoui I, Ly-Sunarram B, Fest $\mathrm{T}$, et al. Improvement of the leukocyte differential performed by flow cytometry using the advanced 2.0 version of the CytoDiff CXP software. Cytometry A. 2014 Aug;85(8):653-7.

9. de Jongste $A H$, Kraan J, van den Broek PD, Brooimans RA, Bromberg JE, van Montfort KA, et al. Use of TransFix ${ }^{\mathrm{TM}}$ cerebrospinal fluid storage tubes prevents cellular loss and enhances flow cytometric detection of malignant hematological cells after 18 hours of storage. Cytometry A. 2013 May 14;86(4):272-9.

10. Brown L, Green CL, Jones N, Stewart JJ, Fraser S, Howell K, et al. Recommendations for the evaluation of specimen stability for flow cytometric testing during drug development. J Immunol Methods. 2015 
Mar;418:1-8.

11. Ng AAP, Lee BTK, Teo TSY, Poidinger M, Connolly JE. Optimal cellular preservation for high dimensional flow cytometric analysis of multicentre trials. J Immunol Methods. 2012 Nov 30;385(1-2):79-89.

12. Canonico B, Betti M, Luchetti F, Battistelli M, Falcieri E, Ferri P, et al. Flow cytometric profiles, biomolecular and morphological aspects of transfixed leukocytes and red cells. Cytometry B Clin Cytom. 2010 Jul;78(4):267-78. 


\section{Legends}

Figure 1. After 2 hours of any conservation method, mean fluorescent intensities (MFI) of CD36, CD19, CD2, CD36, and CD45 are decreased

CD16 expression on neutrophils (Ne), CD19 on B-lymphocytes (LyB), CD2 expression on T\&NK cells (LyT\&NK), CD36 expression on monocytes (Mo), and CD45 expression on total WBC were analyzed after 2 hours of treatment. Fixation methods: storage at room temperature ("No Fix RT"), cold storage ("No Fix $+4^{\circ} \mathrm{C}$ "), Streck Cell Preservative ${ }^{\mathrm{TM}}$ ("streck") or Transfix ${ }^{\mathrm{TM}}$ ("transfix") fixatives. After collection, whole blood was processed as follows before labeling: For Transfix ${ }^{\mathrm{TM}}$ treated samples, $1 \mathrm{~mL}$ of anticoagulated blood was directly fixed in the storage tube and mixed by 5 inversion moves and then stored at $+4^{\circ} \mathrm{C}$ according to the manufacturer's recommendations. For Streck Cell Preservative ${ }^{T M}$ treated samples, $500 \mu \mathrm{L}$ of Streck Cell Preservative ${ }^{\mathrm{TM}}$ were added to $500 \mu \mathrm{L}$ of blood and then stored at room temperature according to the manufacturer's recommendations. Samples were preserved for 2 hours at the appropriate temperature before staining. Control samples (Unfixed samples) were stored either at room temperature or at $4^{\circ} \mathrm{C}$. Whole blood was labeled with the CytoDiff cocktail (Beckman Coulter), events were acquired on an FC500 flow cytometer (Beckman Coulter), and analyzed by CXP 2.0 software (Beckman Coulter) as previously described [8]. Samples were analyzed in 2 centers (Creteil and Rennes). Each center analyzed its own samples and data analysis was performed jointly (O.W.B and M.R.). Box and Whisker plots with the 10-90 percentiles and the outliers are represented for normal $(n=15)$ samples. Repeated- non-parametric- continuous variables were compared using Friedman tests and analyzed using GRAPHPAD 5.0 Prism Software (GraphPad Software, San Diego, CA, USA). ns: non statistically significant. ${ }^{* *} p<.01$ and ${ }^{* * *} p<.001$.

Figure 2. CD45/SSC scattergram is altered after 2 hours in preservative solutions

A normal sample and a pathological sample are shown on a CD45/SSC scattergram. Neutrophils are labeled in pink, eosinophils in orange, monocytes in green, lymphocytes in blue, and blasts in brown (B blasts, left panel) or red (non $\mathrm{B}$ non $\mathrm{T}$ blasts, right panel). On pathological samples \#2, the $\%$ indicates the $\%$ of blast cells found by the CXP autogating. Analyses were performed after 2 hours of sample treatment: Storage at room temperature with absence of fixation ("No Fix RT") or cold storage with no fixation ("No Fix +4"), Streck Cell Preservative ${ }^{\mathrm{TM}}$ ("STRECK") or Transfix"TM ("TRANSFIX") fixatives. 

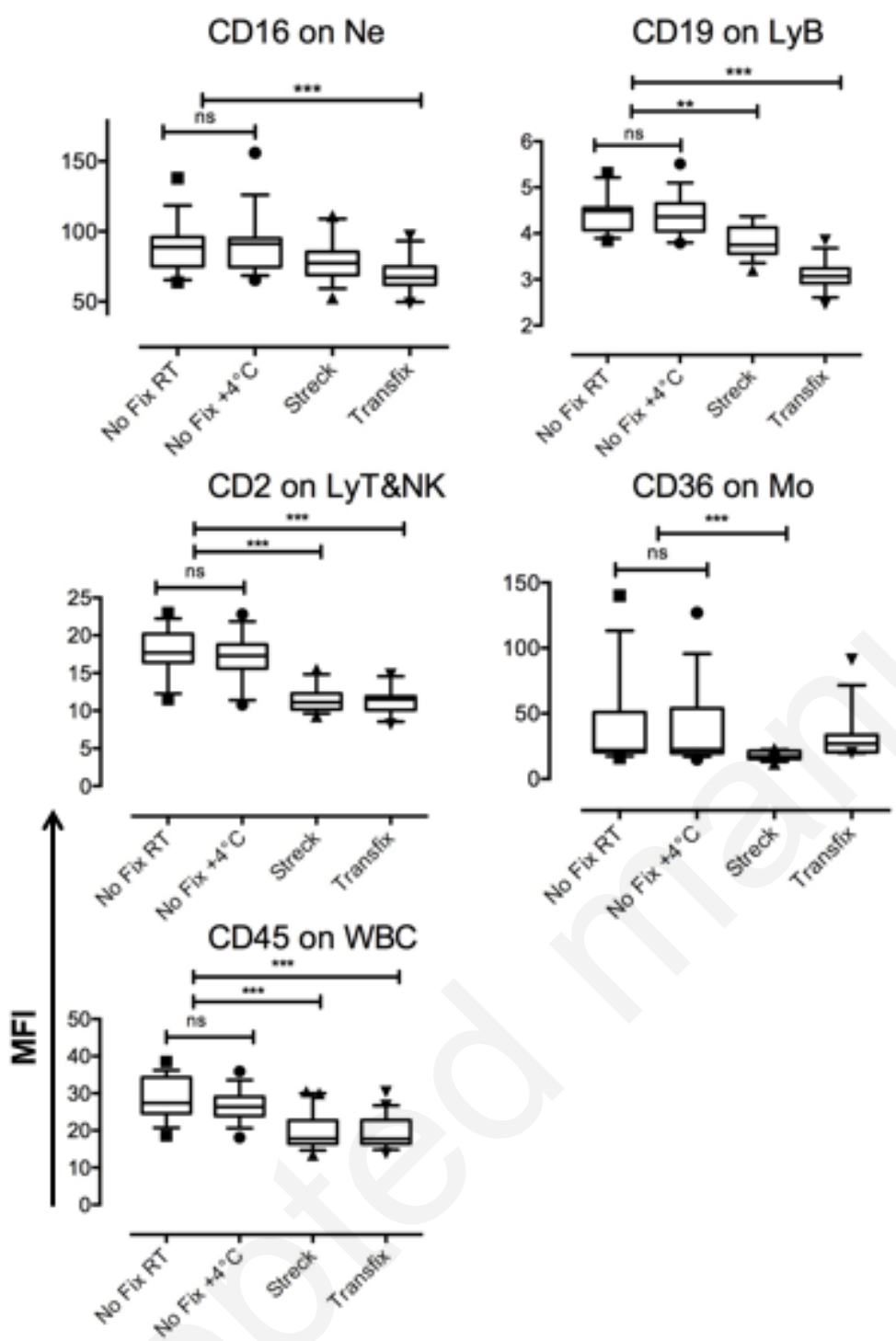
Pathological \#2
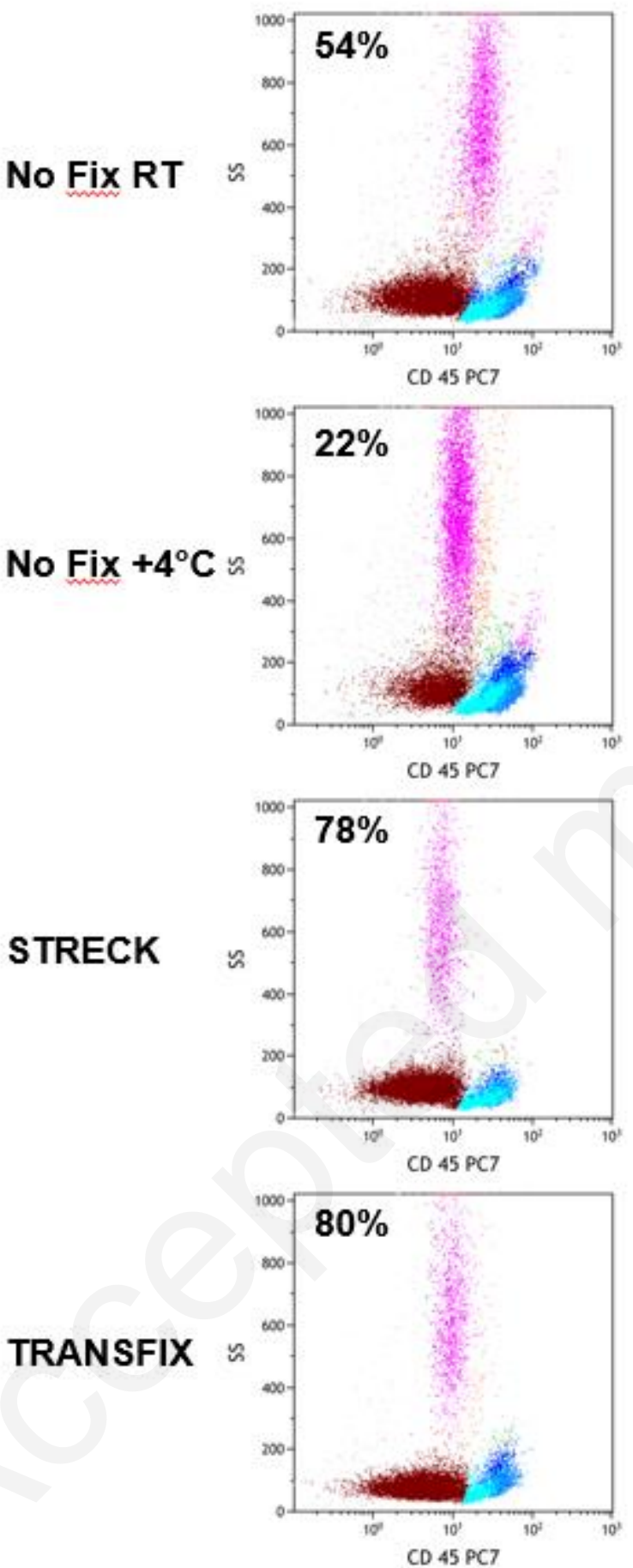

Normal \#7
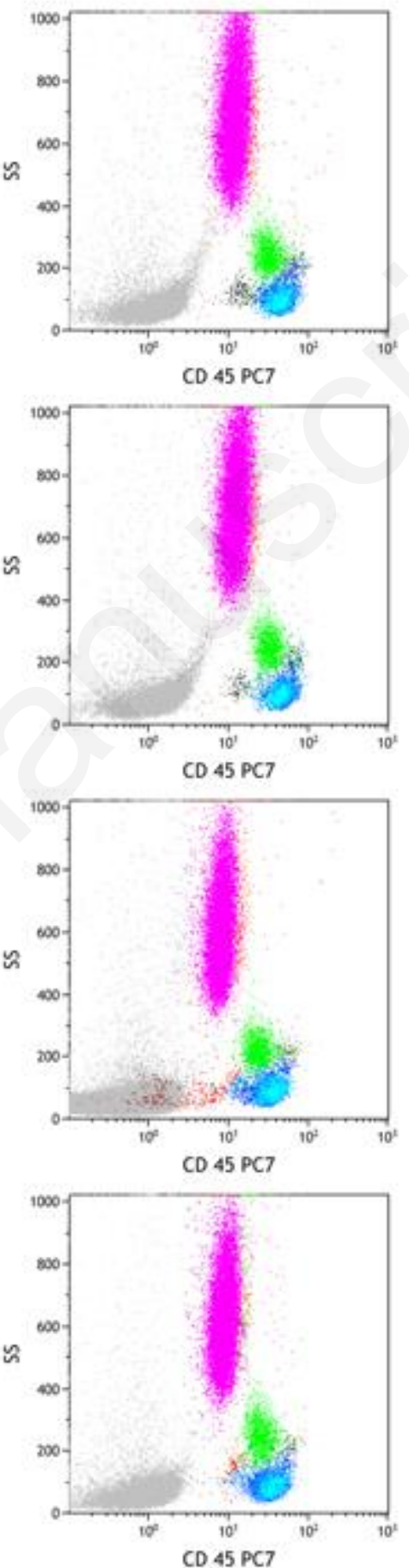